\title{
DIREITO ROMANO E CONSTITUCIONALISMO GLOBAL
}

\author{
ROMAN LAW AND GLOBAL CONSTITUTIONALISM \\ DERECHO ROMANO Y CONSTITUCIONALISMO GLOBAL
}

Rafael Domingo Osle ${ }^{1}$

Licença CC BY:

Artigo distribuído sob os termos Creative Commons, permite uso e distribuição irrestrita em qualquer meio desde que o autor credite a fonte original.

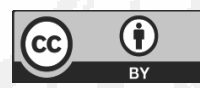

\begin{abstract}
Resumo: O paralelo entre questões contemporâneas e história romana muitas vezes fascina e ilumina. Neste artigo, argumento que o direito romano, que foi uma das várias fontes de inspiração para os fundadores americanos, pode servir hoje como uma inspiração para o constitucionalismo global. Olhar para o direito romano ajuda a reduzir certos preconceitos derivados do atual privilégio do Estado soberano e do paradigma positivista como os únicos modelos genuínos e possíveis para o direito internacional. Esses preconceitos constituem um verdadeiro obstáculo ao desenvolvimento correto do constitucionalismo global. O constitucionalismo global se move inerentemente para além da soberania, do nacionalismo e do positivismo. O direito romano, que precedeu às noções de soberania, nacionalismo e positivismo, permite aos constitucionalistas eliminar do constitucionalismo global quaisquer elementos não fundacionais derivados de um paradigma altamente estatista. A lei romana também constitui um bom antídoto para qualquer tipo de constitucionalismo global extremo que busque estender a linguagem e os modos do constitucionalismo nacional sem filtrá-los e refiná-los suficientemente.
\end{abstract}

Palavras-chave: Constitucionalismo global; direito global; direito romano; soberania; estado-nação; poder constituinte

\begin{abstract}
The parallel between contemporary issues and Roman history often fascinates and illuminates. In this article, I argue that Roman law, which was one of several sources of inspiration for the American founders, can serve today as an inspiration toward global constitutionalism. Looking to Roman law helps reduce certain prejudices derived from the current privileging of the sovereign state and the positivist paradigm as the only genuine and possible models for international law. These prejudices actually hinder the correct development of global constitutionalism. Global constitutionalism inherently moves beyond sovereignty, nationalism, and positivism. Roman law, which preceded notions of sovereignty, nationalism, and positivism, enables constitutionalists to eliminate, from global constitutionalism, any non-foundational elements derived from a highly statist paradigm. Roman law also provides a good antidote to any kind of extreme global constitutionalism that seeks to extend the language and modes of national constitutionalism, without sufficiently filtering and refining them.
\end{abstract}

1 Doutor em Direito pela Universidade de Navarra, Espanha. Docente da Emory University School of Law - Atlanta, GA. Professor de Direito e ICS na Universidade de Navarra, Espanha. E-mail: Rafael.domingosle@gmail.com 
extreme global constitutionalism that seeks to extend the language and modes of national constitutionalism, without sufficiently filtering and refining them.

Key-words: Global constitutionalism; global law; roman law; sovereignty; nation-state; constituent power.

Resumen: El paralelo entre cuestiones contemporáneas e historia romana muchas veces fascina e ilumina. En este artículo, argumento que el derecho romano, que fue una de las varias fuentes de inspiración para los fundadores americanos, puede servir hoy como una inspiración para el constitucionalismo global. Mirar para el derecho romano ayuda a reducir ciertos prejuicios derivados del actual privilegio del Estado soberano y del paradigma positivista como los únicos modelos genuinos y posibles para el derecho internacional. Estos prejuicios constituyen un verdadero obstáculo al desarrollo correcto del constitucionalismo global. El constitucionalismo global se mueve inherentemente más allá de la soberanía, del nacionalismo y del positivismo. El derecho romano, que precedió a las nociones de soberanía, nacionalismo y positivismo, permite a los constitucionalistas eliminar del constitucionalismo global cualesquier elementos no fundacionales derivados de un paradigma altamente estatista. La ley romana también constituyó un buen antídoto para cualquier tipo de constitucionalismo global extremo que busque extender el lenguaje y los modos del constitucionalismo nacional sin filtrarlos y refinarlos suficientemente.

Palabras - clave: Constitucionalismo global; derecho global; derecho romano; soberanía; estadonación; poder constituyente.

\section{INTRODUÇÃO}

Este artigo tenta contribuir para o debate acadêmico sobre o constitucionalismo global $^{2}$, baseando-se em ideias e argumentos do direito romano. Essa abordagem não envolve nem nostalgia nem anacronismo. Assim como os princípios e os valores constitucionais romanos iluminaram a decisão dos autores da Constituição dos Estados Unidos em $1787^{3}$, a história constitucional romana também pode ter

2 O constitucionalismo global é uma expressão abrangente usada para captar a necessidade de princípios, valores, padrões, procedimentos e mecanismos constitucionais aplicados além do Estado. $O$ termo denota um modo de pensar sobre governança global que promove uma compreensão mais profunda dos fundamentos do direito internacional e do ordenamento jurídico global, aplicando a linguagem do direito constitucional. De fato, o direito internacional está se movendo, pelo menos em algumas áreas, de um paradigma baseado na soberania do Estado e consensualismo para um novo baseado na constitucionalização progressiva. Para uma visão geral do debate atual sobre o constitucionalismo global, bem como para a bibliografia selecionada sobre este tema, ver Anne Peters, "Constitucionalismo Global", em Michael T Gibbons, ed., A Enciclopédia do Pensamento Político (Malden: John Wiley and Son, 2015) disponível em: http://www.mpil.de/files/pdf4/Peters_Global_Constitutionalism3.pdf. Veja também Jeffrey L. Dunoff e Joel P. Trachtman, eds., Governando o mundo? Constitucionalismo, Direito Internacional e Governança Global (Nova York, Cambridge: Cambridge University Press, 2009); Jan Klabbers, Anne Peters e Geir Ulfstein, A constitucionalização do direito internacional (Oxford, Nova York: Oxford University Press, 2010); Surendra Bhandari, Constitucionalismo Global e o Caminho do Direito Internacional (Leiden, Boston: Brill Nijhoff, Leiden, 2016); Anthony F. Lang Jr. e Antje Wiener, ed., Handbook on Global Constitutionalism (Cheltenham e Northampton, MA: Edward Elgar Publishing, 2017); Takao Suami, Mattias Kumm, Anne Peters e Dimitri Vanoverbeke, Constitucionalismo Global de Perspectivas Européias e do Leste Asiático (Cambridge, Nova York: Cambridge University Press, 2018).

3 Veja David J. Bederman, A Fundação Clássica da Constituição Americana (Cambridge e Nova York: Cambridge University Press, 2008). 
um impacto prático na experiência constitucionalista global ${ }^{4}$. Isso pode ocorrer especialmente se considerarmos a palavra "constituição" (do latim constituere, para configurar, para estabelecer) no sentido mais amplo e tradicional - isto é, ligada a conceitos de comunidade, freios e contrapesos e participação, em vez de estreito sentido moderno das constituições liberais, democráticas e formais associadas às nações soberanas. Enquanto os americanos podem dizer com razão, "Nós, o povo dos Estados Unidos", os romanos, muitos séculos antes, foram capazes de declarar "Nós, o povo de Roma". Parece-me, assim, que o direito público romano pode servir de modelo para os constitucionalistas globais interessados em desenvolver princípios, regras, mecanismos e padrões para ordenar a comunidade humana global emergente, bem como sua ordem legal incipiente correlata - a chamada lei global 5 .

Por ser anterior ao estado-nação, o direito romano constitui um bom antídoto contra qualquer tipo de constitucionalismo extremo que busque estender a linguagem e os modos de constitucionalismo nacional não filtrado ou não refinado. Mas a lei romana também constitui um bom antídoto contra aqueles que são céticos sobre a viabilidade do constitucionalismo global. Olhando para a lei romana, tempera a visão de que o atual estado soberano positivista constitucional é o único paradigma genuíno e possível. Esse preconceito, na minha opinião, constitui um verdadeiro obstáculo ao desenvolvimento correto do constitucionalismo global, que é geneticamente pós-soberano, pós-nacionalista e pós-positivista. Se o constitucionalismo global é pós-todas essas coisas, o direito romano era, por assim dizer, pré-tudo: pré-soberano, pré-nacionalista e pré-positivista. O constitucionalismo global e o direito romano estão, portanto, ligados por serem não soberanos, não nacionalistas e não positivistas. Eles representam o passado e o futuro da lei, embora não o presente, que é principalmente soberanista, nacionalista e positivista.

O paradigma do direito romano não constitui uma estrutura perfeita para o constitucionalismo global, uma vez que o constitucionalismo global não pode voltar atrás no tempo para se tornar pré-soberano, pré-nacionalista e pré-positivista, como era o direito romano. Além disso, os romanos não

$4 \quad$ Adam Smith e Edward Gibbon também usaram o exemplo romano para ilustrar as relações entre a Grã-Bretanha e suas colônias norte-americanas. Sobre este tópico, ver Harold James, The Roman Predicament: Como as Regras da Ordem Internacional Criam a Política do Império (Princeton, NJ: Princeton University Press, 2006), esp. p. 141

5 Sobre a ideia de lei global, ver Neil Walker, Intimations of Global Law (Cambridge, Nova York: Cambridge University Press, 2015). Veja também Rafael Domingo, A Nova Lei Global (Cambridge, Nova York: Cambridge University Press, 2010). 
compartilhavam certos valores fundamentais do constitucionalismo global, como o conceito de igualdade humana radical sob a lei, os princípios da democracia liberal, o princípio da não discriminação, ou o dever moral de evitar a guerra, entre outros ${ }^{6}$. No entanto, alguns aspectos do direito romano podem fornecer inspiração para os constitucionalistas cosmopolitas. Em outras palavras, o que o direito romano oferece ao constitucionalismo global não é um modelo imitável, mas genialidade, visão, ideias e estímulo.

Deixe-me oferecer três advertências antes de desenvolver meu argumento. Primeiro, meu esforço não é prejudicado pelo fato de que o direito romano foi fundamental para o amadurecimento e progresso da doutrina clássica do direito internacional, que o novo constitucionalismo procura superar. Essa tensão histórica é apenas uma consequência da capacidade polivalente do direito romano de iluminar até empreendimentos opostos ${ }^{7}$. Por outro lado, o direito internacional clássico foi fundado não apenas na ideia romana da lei das nações (ius gentium) ${ }^{8}$, mas também, e especificamente, na lei romana dos contratos e da propriedade. As leis que regem os tratados internacionais devem muito ao direito romano dos contratos. O mesmo pode ser dito da lei romana da propriedade em relação à doutrina do território soberano ${ }^{9}$. O constitucionalismo global, no entanto, poderia se beneficiar de outras ideias e valores da constituição da República Romana que estão no cerne do direito público romano.

Minha segunda advertência é que, embora a lei romana apoiasse um império e, portanto, uma perspectiva imperialista, esse fato não reduz as vantagens potenciais da inspiração do direito romano. Pelo contrário, a transição

6 Para uma visão geral do direito romano, ver David Johnston, ed., The Cambridge Companion to Roman Law (Cambridge, Nova York: Cambridge University Press, 2015); Paul de Plessis, Clifford Ando e Kaius Tuori, The Oxford Handbook of Roman Law and Society (Oxford: Oxford University Press, 2017); e Rafael Domingo, Lei Romana: Uma Introdução (London, New York: Routledge, 2018). Ver também Franz Wieacker, Römische Rechtgeschichte: Quellenkunde, Rechtsbildung, Jurisprudenz e Rechtsliteratur I (Munique: Beck Verlag, 1988).

7 A história do direito internacional oferece muitos exemplos de argumentos contraditórios baseados no direito romano.

8 Sobre esse tópico, veja Max Kaser, lus gentium (Viena, Colônia e Weimar: Böhlau, 1993).

9 Sobre a relação entre o direito romano e o direito internacional, ver Benedict Kingsbury e Benjamin Straumann, orgs., The Roman Foundations of the Law of Nations: Alberico Gentili e Justice of Empire (Oxford e New York: Oxford University Press, 2010); Benjamin Straumann, Direito Romano no Estado da Natureza: os fundamentos clássicos do direito natural de Hugo Grotius (Nova York e Cambridge: Cambridge University Press, 2015). Sobre a relação entre o direito romano da propriedade e o direito internacional, ver Randall Lesaffer, "Argumento do Direito Romano no Direito Internacional Atual: Prescrição Ocupacional e Aquisitiva", no European Journal of International Law 16 (2005): 25-58. 
da República Romana para o Império Romano durante o Principado (27 a.C. a 284 d.C.), inaugurada pelo imperador Augusto (63 a.C. - 14 d.C.), implicou uma ruptura com a ordem constitucional republicana e os princípios que apoiam o meu argumento. A revolução romana iniciada por Augusto ${ }^{10}$ revelou o falso universalismo do império, assim como qualquer tentativa constitucional de transformar o mundo em um estado global desvelará o falso universalismo de um constitucionalismo global espúrio. Aqui, também a história romana é uma chave heurística para a vida.

Minha terceira advertência é simplesmente um lembrete de que a comunidade humana global é universal porque inclui a humanidade como uma totalidade e em sua totalidade. Assim, a comunidade global merece uma estrutura única, um modelo de lei feito sob medida. Portanto, a linguagem do direito romano, que governava uma comunidade política não universal e instrumental, deveria ser transposta com muito cuidado, e sempre de maneira limitada, para a comunidade global contemporânea, que é intrinsecamente universal e necessária ${ }^{11}$.

\section{APLICANDO ALGUMAS LIÇÕES DO DIREITO ROMANO AO CONSTITUCIONALISMO GLOBAL}

Nesta seção, descreverei dez bons exemplos que o direito romano fornece ao constitucionalismo global. Primeiro, explicarei o relevante princípio romano, o valor ou o fato social, e então me referirei à sua potencial tradução para o reino do constitucionalismo global. Eu acomodarei minhas explicações do direito romano ao propósito deste artigo, especialmente dirigido aos constitucionalistas.

2.1. Um espírito cosmopolita. A lei romana oferece ao constitucionalismo global um bom exemplo de apoiar o cosmopolitismo como um ideal político e uma atitude humana nobre ${ }^{12}$. O espírito estoico, que animava quase todos

10 Veja o famoso livro escrito por Ronald Syme, A Revolução Romana (Oxford, Nova York: Oxford University Press, reimpressão de 2002). Veja também Benjamin Straumann, Crise e Constitucionalismo: Pensamento Político Romano da Queda da República à Era da Revolução (Oxford, Nova York: Oxford University Press, 2016)

11 Expliquei as diferenças em Rafael Domingo, "A Comunidade Humana Global", Chicago Journal of International Law 13.1 (2012): 563-587.

12 Veja Thomas Pangle, "Cosmopolitismo romano. Os estóicos e Cícero", em Lee Trepanier e Khalil M. Habib, ed., Cosmopolitanism na Era da Globalização (Lexington: The University Press de Kentucky, 2011) 40-69. Ver também Martha C. Nussbaum, "Kant e cosmopolitismo estoico", no Journal of Political Philosophy 5.1 (1997): 1-25. 


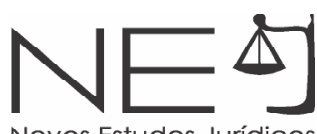

os juristas romanos e muitos dos pensadores romanos durante a república e o império (Cícero, Sêneca, Marco Aurélio), tinha um caráter cosmopolita e constituía a principal influência na educação jurídica romana ${ }^{13}$. Cícero aplicou ideias estoicas às relações internacionais, fazendo afirmações relevantes sobre os deveres das comunidades e dos povos uns para com os outros, bem como cunhando a expressão ius gentium (lei das nações) no processo ${ }^{14}$. Segundo Cícero, a raça humana é naturalmente e harmonicamente unida de maneira semelhante à relação das partes do corpo entre si. É por isso que "a natureza não nos permite aumentar nossos meios, nossos recursos e nossa riqueza despojando os outros"15. O mesmo princípio, de acordo com Cícero, é estabelecido "não apenas na natureza, ou seja, na lei das nações, mas também nas leis de povos individuais, através dos quais a comunidade política de cidades individuais é mantida: não se permite que alguém prejudique outro em benefício próprio. ${ }^{16 "}$

Entre os últimos juristas romanos clássicos, Ulpian era o mais cosmopolita. Suas visões filosóficas, profundamente influenciadas pelo estoicismo, eram igualitárias, e ajudaram a resolver os novos desafios jurídicos decorrentes da extensão da cidadania a todos os indivíduos livres do império pela constituição de Antonine (212 EC). Ulpian tentou converter o direito romano em um sistema legal mais cosmopolita, adequado às necessidades de uma sociedade multicultural e baseado nos valores de liberdade, dignidade, universalidade e igualdade. Nesse sentido, o estudioso contemporâneo Tony Honoré o considera um pioneiro do movimento pelos direitos humanos ${ }^{17}$.

O constitucionalismo global é fundamentalmente cosmopolita ${ }^{18}$. O que na Roma antiga era um ideal e uma aspiração compartilhada por filósofos e

13 Para uma visão geral, veja Anthony Padgen, "Estoicismo, Cosmopolitismo e o Legado do Imperialismo Europeu", Constellations 7.1 (2000): 1-22.

14 A menção mais significativa pode ser encontrada no ensaio moral de Cícero On Duties 3. 69, editado por M.T. Griffin e E. M. Atkins (Cambridge, Nova lorque: Cambridge University Press, 1991). Depois de falar da sociedade no sentido amplo de unir todas as pessoas umas com as outras, Cícero se referiu a sociedades menores compostas de gentes, ou aquelas formadas em cidades.

15 Cicero, On Duties 3.22.

16 Cicero, On Duties 3.23.

17 Tony Honoré, Ulpian: Pioneiro dos Direitos Humanos, 2. ed. (Oxford e Nova York: Oxford University Press, 2002).

18 Para uma visão geral, ver Pauline Kleingeld e Eric Brown, "Cosmopolitanism", em Edward N. Zalta, ed., A Enciclopédia de Stanford de Filosofia (Outono de 2014 Edition), URL = <https://plato.stanford.edu/archives/ fall2014 / entradas / cosmopolitismo />. Veja também, Seyla Benhabib, ed., Another Cosmopolitanism (Oxford, Nova York: Oxford University Press, 2006). 
advogados, é hoje uma realidade verificável: todos os seres humanos são de fato membros de uma comunidade humana global emergente na qual compartilham necessidades, interesses e projetos. O constitucionalismo global alega que essa comunidade universal também deve ser governada por lei, e que cada nação deve ser cosmopolita em espírito, no sentido de preservar, assistir e sustentar a ordem jurídica global ${ }^{19}$. A lei romana oferece bons argumentos para a legitimação e a justificação dessas duas reivindicações ${ }^{20}$. Também abre as portas para a chamada abordagem pós-nacionalista, que insiste em reformular a ideia do Estado-nação em face da globalização e da reterritorialização ${ }^{21}$.

2.2. Constituição não escrita. A linguagem do constitucionalismo em relação à comunidade global se beneficia da experiência do direito romano, que estabeleceu um modelo de comunidade sem uma constituição codificada.

Roma nunca teve uma constituição escrita. Em vez de um único texto, a constituição de Roma era um conjunto vivo e ágil de normas legais e políticas. ${ }^{22}$ Foi um longo, contínuo e complexo processo de constituição da República, criando e desenvolvendo instituições, poderes políticos, princípios e regras, práticas e funções, bem como relações institucionais mútuas. A constituição de Roma nunca foi reduzida a um documento; em grande parte não escrita e evoluindo ao longo do tempo, a constituição romana foi baseada na tradição, mas não em precedentes obsoletos. A eleição anual de dois cônsules, a existência e as funções do Senado e a reunião de diferentes assembleias populares para diferentes finalidades, todos eram elementos da Constituição, mas não eram regulamentados por estatutos escritos. A constituição romana acomodou mudanças nas circunstâncias com novas ideias e argumentos. Por essa razão, a constituição romana era inescapavelmente controversa, intrinsecamente política e sempre se abre para testes em debates públicos. Os romanos se orgulhavam

19 Na mesma linha, ver Mattias Kumm, "A virada cosmopolita no constitucionalismo: uma concepção integrada do direito público", Indiana Journal of Global Legal Studies 20 (2013): 605-628.

20 Veja Rafael Domingo, "Gaius, Vattel, e o Novo Paradigma Global da Lei", European Journal of International Law 22.3 (2011): 627-647; e Domingo, "A Nova Comunidade Humana Global".

21 Embora o nacionalismo pareça estar em ascensão nas últimas décadas como resultado do colapso da antiga União Soviética e do aumento da imigração, entre outras razões, a ideia do Estado-nação continua a se deteriorar.

22 Excelentes visões gerais da constituição romana são oferecidas em Wolfgang Kunkel, Uma Introdução à História Jurídica e Constitucional Romana, 2. ed., Trad. por J. M. Kelly (Oxford: Clarendon Press, 1973) e Andrew Lintott, A Constituição da República Romana (Oxford e Nova York: Oxford University Press, 1999). Mais recentemente, ver Benjamin Straumann, Crise e Constitucionalismo: Pensamento Político Romano da Queda da República à Era da Revolução (Oxford e Nova York: Oxford University Press, 2016). 
da superioridade de sua constituição por causa de sua estabilidade, estrutura equilibrada, atribuição clara de funções e disciplina sólida ${ }^{23}$. O grande historiador grego Políbio (200-118 a.C.) associou o sucesso militar romano à perfeição e à grandeza da constituição de Roma ${ }^{24}$, que permitiu a Roma trazer quase todo o mundo do Mediterrâneo sob seu domínio em apenas cinquenta e três anos.

Políbio e Cícero entendiam a constituição republicana como uma constituição mista ${ }^{25}$. Combinou elementos da aristocracia (o Senado) com a democracia (o povo) e a monarquia (os cônsules). Segundo Cícero ${ }^{26}$, tal constituição tem um extenso componente de igualdade; proporciona harmonia e estabilidade e previne a corrupção. Constituições simples levam a versões corrompidas de cada tipo de regra, produzindo um déspota em vez de um rei, uma oligarquia em vez de uma aristocracia e uma turba caótica em vez de uma democracia. Em contraste, a constituição romana fornecia um sistema de freios e contrapesos baseado em uma combinação de poderes e vetos de magistrados, e de controle político dos magistrados pelo Senado e pelo povo. A grandeza da constituição romana se refletiu em uma frase muito curta: "o Senado e o povo de Roma" (Senatus Populusque Romanus, abreviado como SPQR). Como Cícero explicou por meio de Catão, o Velho, uma das razões pelas quais a constituição romana foi superior aos outros foi que ela foi estabelecida não pela grande habilidade de um único homem, mas pela liderança de muitos, e não no curso de uma vida, mas sobre eras e gerações ${ }^{27}$.

A experiência constitucional de Roma ajuda os constitucionalistas internacionais a substituir o paradigma estatal por um paradigma global. A comunidade global não precisa de uma constituição escrita, abrangente e totalizadora, como se fosse a lei suprema de um estado mundial. O paradigma global não precisa se assemelhar às características constitucionais de um

23 Cicero, On the Commonwealth 1.70, ed., James E. G. Zetzel (Cambridge: Cambridge University Press, 1999).

24 Polybius, The Histories 1.1.5, ed., F. W. Walbank, Christian Habicht, e W. R. Paton, Loeb Classical Library, vol. 1 (Cambridge, MA: Harvard University Press, 2010).

25 Veja Políbio, As Histórias 6.5.11-18, ed., Walbank et al., Vol. 3; e Cicero On the Commonwealth 1.69, ed., James E. G. Zetzel (Cambridge: Cambridge University Press, 1999). Políbio, no entanto, não usa a expressão "constituição mista" como tal. Para Cícero, a constituição mista era principalmente um instrumento para restaurar o equilíbrio constitucional perdido, um último recurso para salvar a república, mas sua ordem constitucional preferida não era mista. Veja Mitj Sadek, "Cícero e a Constituição Mista (res publica mixta)," Keria: Studia Latina e Graeca 11/2 (2009): 29-41; e Jed W. Atkins, Pensamento Político Romano (Cambridge, Nova York: Cambridge University Press, 2018), 11-36.

26 Cicero, sobre a Commonwealth 1.69.

27 Cicero, sobre a Commonwealth 2.1.2. 
Novos Estudos Jurídicos

Estado-nação. Qualquer tentativa de estabelecer uma constituição abrangente fracassará tanto no nível nacional quanto no global. Em vez disso, a comunidade global precisa ser organizada sob uma ordem legal global coerente que garanta a harmonia global, a estabilidade e o desenvolvimento e limite o uso do poder. Essa ordem legal exige, é claro, algum grau de constitucionalização, mas não uma constituição escrita abrangente.

2.3. Respeito pela tradição. Os romanos possuíam uma especial veneração por tradição, precedente e autoridade. Eles estimavam os costumes ancestrais (mores maiorum), os modos de seus antepassados e suas ideias tradicionais, particularmente no campo do direito. Romanos preservaram um notável espírito de tradicionalismo. Eles estavam relutantes em abolir qualquer lei válida, porque consideravam seus ancestrais parte do povo romano. Romanos tinham uma profunda aversão por mudanças desnecessárias e por uma grande desconfiança de novidades. Eles não gostavam de inovações rápidas, modificações apressadas e atitudes revolucionárias. Eles tentaram construir o que seus ancestrais tinham construído, respeitando primorosamente as principais decisões legais no passado. Essa atitude conservadora explica a preservação secular do formalismo rígido e severo que caracteriza o sistema legal primitivo. No coração do conservadorismo e do respeito pela tradição dos romanos estava a ideia de que a justiça, como uma vontade individual e coletiva constante, contínua e perpétua, exigia um desenvolvimento histórico cuidadoso e gradual. O líder era o povo como uma comunidade eterna, não este ou aquele legislador particular.

A natureza evolutiva do direito romano constitui um bom exemplo para o constitucionalismo global, porque a estrutura conceitual integrativa do constitucionalismo global deve ser evolucionária e não revolucionária. O constitucionalismo global deve respeitar a tradição. O direito internacional é principalmente uma tradição europeia ${ }^{28}$. O constitucionalismo é uma tradição europeia e americana. Mas a universalidade do constitucionalismo global não deveria, de modo algum, excluir o respeito pela particularidade da tradição. Como assinalou Martti Koskenniemi, "se o universal não tem representante próprio,

28 Neste sentido, ver o artigo desafiador de Martti Koskenniemi, "Direito Internacional na Europa: Entre Tradição e Renovação", European Journal of International Law 16 (2005): 113-124. 
então a particularidade em si não é um escândalo"29. O particular na verdade transcende a si mesmo quando é aceito pelos outros como universal. Para meus propósitos, isso significa que o constitucionalismo global será universalizado quando for universalmente aceito como um elemento inerente à comunidade humana global e uma política adequada de direito global.

2.4. Paradigma do estado não soberano. A lei romana pode ajudar o constitucionalismo global a transcender o paradigma estatal baseado na soberania. O estado-nação soberano é uma abstração moderna bastante contrária ao espírito romano. Politicamente, o povo romano foi investido não com soberania, mas com maiestas (majestade), um dos princípios fundamentais da República Romana ${ }^{30}$. Maiestas era um conceito original sem palavra equivalente em grego. Maiestas vem do maior (maior) e expressa a ideia da superioridade e grandeza do povo romano. Em virtude de sua superioridade, Roma exigia respeito e submissão de outros povos, embora essa exigência não implicasse uma rejeição da liberdade dos outros. De fato, a liberdade de outros povos era considerada uma condição necessária das maiestas romanas. A transferência da majestade do povo para o imperador começou com Augusto e foi completada pelo início do domínio no final do terceiro século. Quando a majestade do imperador cresceu, a estrutura republicana declinou, mas a majestade continuou sendo a medida de autoridade.

A ideia de soberania, por outro lado, representa um absolutismo francês e uma adaptação exclusiva da majestade romana. A soberania apareceu pela primeira vez em Les six livres de la République (1576) ${ }^{31}$, de Jean Bodin. Bodin entendeu a soberania como o poder absoluto e permanente que uma república

29 Koskenniemi, "Direito Internacional na Europa", 115.

30 Em maiestas, ver Bernhard Kübler, "Maiestas", em agosto Friedrich Pauly e George Wissova, editores, Paulys Realencyclopädie der classischen Altertumswissenschaft: Lysimichos bit Mantike, vol. 14.1 (Stuttgart, Munique: Alfred Druckenmüller 1928), cols. 452-459; R. A. Bauman, The Crimen Maiestatis na República Romana e Principado de Augustan (Joanesburgo: Witwatersrand University Press, 1970); Rafael Domingo, Auctoritas (Barcelona: Ariel, 1999), 23-25; Álvaro Jacobo Pérez, Auctoritas et maiestas. História, programa e iconografía na moneda de Vespasiano (São Vicente do Rasgo: Publicaciones da Universidade de Alicante, 2003); e Davide Salvo, "Maiestas", em Roger S. Bagnall, Kai Brodersen, Craige B. Champion, Andrew Erskine e Sabine R. Huebner, editores, A Enciclopédia da História Antiga (Malden, MA: Blackwell Publishing, 2013), 4236-4238, com bibliografia em 4238.

31 Os antecedentes medievais - sobretudo os que começam com a fórmula rex superiorem non recognocens in regno suo est imperator - podem ser encontrados em Francesco Calasso, I glossatori et la teoria della sovranità, 3. ed. (Milan: Giuffrè, 1957). A teoria, no entanto, precisa de revisão. 
exerce em um determinado contexto: "la puissance absolue et perpetuelle d'une République" [o poder absoluto e perpétuo de uma comunidade política] ${ }^{32}$. Na versão latina desse trabalho, a definição de maiestas parece esclarecida e traduzida livremente, inspirada em parte pela frase de Ulpian, princeps legibus solutus: "O imperador não está limitado por estatutos" 33 . A soberania era, portanto, um poder exclusivo e excludente nas mãos do príncipe, que poderia impor leis sobre seus súditos sem o seu consentimento e sem se comprometer com eles. A soberania assim concebida implicava uma indivisibilidade absoluta de poder dentro de uma comunidade e uma absoluta independência nas relações internacionais. Esse conceito de soberania - que novamente substituiu o conceito romano de maiestas - fechou definitivamente as portas para um sistema internacional harmoniosamente ordenado, em vez de padronizar artificialmente uma constelação de estados, cada um com poderes plenos em seu respectivo território cercado por fronteiras.

Evidentemente, resta pouco deste conceito inicial de soberania principesca no direito internacional vigente, mas todo o sistema do direito internacional foi, de certo modo, viciado por essa ideia territorial excludente de soberania. Além disso, se a própria categoria do direito internacional parece estar ultrapassada em nosso mundo globalizado, é provavelmente por causa das restrições impostas pela ideia de soberania. A soberania foi essencial para a criação de uma lei internacional baseada na coexistência, mas é um verdadeiro obstáculo ao desenvolvimento de um direito internacional baseado na cooperação e na solidariedade. A ideia de soberania deve ser revisada para que seja compatível com os princípios e os valores do constitucionalismo global. As opções parecem estar adotando uma abordagem soberana pluralista ou substituindo o conceito de soberania por um novo conceito político que capta a essência da comunidade global como diferente do estado global. Isso não significa

32 ean Bodin, Les seis libras da República, vol. 1 (Paris: Librairie Arthème Fayard, 1986), 179. Bodin usa o termo latino maiestas como sinônimo de soberania. Assim, por exemplo, no capítulo 10 do livro 1, que trata de "Des vrayes marques de souveraineté" (pp. 245-341), ele fala de "la première marque de la souveraineté" (p. 306), mas de "la seconde marque de majesté" (p. 310). Para uma biografia intelectual de Bodin, ver Howell A. Lloyd, Jean Bodin, "Este homem eminente da França. Uma biografia intelectual (Oxford, Nova York: Oxford University Press, 2017). Sobre a ideia de soberania, ver Daniel Lee, Soberania Popular no Pensamento Constitucional Moderna Inicial Oxford, Nova York: Oxford University Press, 2016).

33 A propósito do comentário de Ulpian sobre a legislação expirada de Augustus, ver Ulpian, Digest 1.3.31, ed., Alan Watson, The Digest de Justiniano (Filadélfia: University of Pennsylvania Press, 1985). 


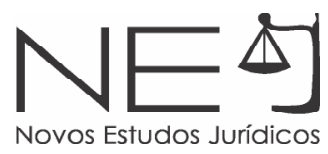

que a soberania não tenha papel no novo paradigma global. A soberania poderia continuar como um conceito instrumental e útil, mas somente após sua reformulação ${ }^{34}$. O papel dos constitucionalistas globais é livrar a ideia de soberania de seu lado negro, que envolve exclusões, limites, impunidade e falta de solidariedade ${ }^{35}$. Se o direito romano é pré-soberano, o constitucionalismo global deve ser definitivamente pós-soberano.

2.5. Uma ideia integrada de direito público. Ulpian grosseiramente definiu o direito público ${ }^{36}$ como a lei que dizia respeito ao estado da comunidade romana (quod ad statum rei Romanae spectat). Em contraste, ele definiu o direito privado como a lei que rege as relações entre indivíduos privados (ad singulorum utilitatem). Em geral, o direito público foi estabelecido para o interesse da comunidade política ou do povo. Abrange tudo o que não se preocupa com o interesse privado dos cidadãos individuais. $O$ direito público tratava da constituição, da administração e do funcionamento da comunidade política romana. Integrou e combinou religião e administração da comunidade política. Ele estava preocupado com magistrados, sacerdotes e coisas sagradas. A lei pública emanou basicamente de assembleias populares e do Senado e depois do imperador também.

Enquanto o direito público era um produto coletivo de gerações de senadores e magistrados, o direito privado era uma manifestação do livre arbítrio do indivíduo. Era uma expressão de direitos e liberdades individuais, embora não fosse governada apenas por interesse próprio. O direito privado manteve a ideia do dever moral. A diferença prática mais importante entre o direito público romano e o direito privado era que "o direito público não pode ser modificado por acordos celebrados entre particulares" ${ }^{37}$. Essa lei imutável é exatamente o que hoje chamaríamos de ius cogens. No entanto, no cerne do direito público e privado estava a ideia de que o direito público não poderia eclipsar ou substituir o direito privado. No direito romano, o direito público

34 Sobre a compatibilidade entre soberania e constitucionalismo além do Estado, ver Jean L. Cohen, Globalization and Sovereignty (Nova York, Cambridge: Cambridge University Press, 2012).

35 Na mesma linha, Martti Koskenniemi, "Direito Internacional no Mundo das Idéias", em James Crawford e Martti Koskenniemi, ed., Direito Internacional (Cambridge, Nova York: Cambridge University Press, 2012), 58

36 Veja Ulpian, Digest 1.1.1.2.

37 Papinian, Digest 2.14.38, ed., Alan Watson, The Digest de Justiniano (Filadélfia: University of Pennsylvania Press, 1985). 
era uma expansão do direito privado, e não o contrário, porque o indivíduo - o cidadão -, e não a comunidade política, era o centro do sistema jurídico romano. O direito público procedia do direito privado. Este modelo original da construção da lei, de baixo para cima e não de cima para baixo, deveria ser transferido para todas as esferas legais, incluindo o constitucionalismo global, tradicionalmente estabelecido de cima para baixo.

No pensamento Ciceroniano, o interesse público (utilitas rei publicae) e a estabilidade (salus) eram os objetivos gêmeos do direito público ${ }^{38}$. O interesse público serviu como um princípio para legitimar novos estatutos, um padrão para interpretação legal e um guia para a atividade jurisprudencial. Papinian ${ }^{39}$ mencionou o interesse público como o último fundamento para a validade da lei pretoriana, e Ulpian ${ }^{40}$ não hesitou em colocar a ideia de utilitas no centro de qualquer mudança legal: "na determinação de novas regras, há uma clara vantagem (utilitas) em vista, se uma lei que foi considerada apenas por um longo tempo deve ser modificada." Baseando-se na filosofia grega e na compreensão Ciceroniana de utilitas, juristas clássicos invocaram abundantemente a ideia de utilitas (no sentido geral de praticidade, interesse social e boa política) como uma boa razão para explicar a aceitação de uma solução jurídica concreta e pragmática, em vez de outra solução baseada em um raciocínio estritamente lógico e dogmático.

O direito público moderno é o resultado da necessária secularização, racionalização e positivação ${ }^{41}$. Ainda assim, o conceito essencial romano de utilitas deve continuar sendo vital. A teoria da soberania prevaleceu durante séculos como a base do direito público, mas deveria ser substituída pelas ideias de serviço público ${ }^{42}$, solidariedade e funcionalidade. Estes devem estar no centro

38 Cicero, On Invention 1,68, ed., H. M. Hubbell, Loeb Classical Library (Cambridge, MA: Harvard University Press, 1949).

39 Papinian, Digest 1.1.7.1.

40 Ulpian, resumo 4.1.2.

41 Para o entendimento moderno do direito público, ver Martin Loughlin, The Idea of Public Law (Oxford: Oxford University Press, 2003), e Martin Loughlin, Fundações do Direito Público (Oxford, Nova York: Oxford University Press, 2010).

42 Veja Léon Duguit, Lei no Estado Moderno, trad. por Frida e Harold Laski (Nova York: B. W. Huebsch, 1919), 32. 
do constitucionalismo global também ${ }^{43}$. Um excessivo emaranhado de soberania e direito público leva a uma fragmentação do direito público. Em contraste, uma ideia normativa mais inclusiva de direito público relacionada com seu propósito (ou causa última) constitui uma fonte de integração global.

2.6. Recuperar a ideia de necessidade como fonte de lei vinculante. Para os romanos, a necessidade (necessitas) era uma fonte de lei obrigatória ${ }^{44}$. Necessitas era a deusa romana que personificava a força constrangedora do destino, 0 inevitável. Ela foi identificada com a deusa grega Ananke e foi descrita como uma poderosa deusa que caminhou diante de Fortuna carregando pregos e cunhas de latão ${ }^{45}$ para consertar os decretos do Destino ${ }^{46}$. Opondo-se ao livre-arbítrio, a necessidade é uma força ou influência que compele uma pessoa involuntária ou um grupo de pessoas a agir ${ }^{47}$.

A necessidade afeta a lei de duas maneiras diferentes. Às vezes, a alegação de necessidade deve ser levada em consideração para justificar legalmente um afastamento da lei ordinária. Essa é, de fato, a prática referente à doutrina da necessidade no direito internacional, que se baseia na regra de que a lei não se aplica quando a necessidade entra em jogo (cessat lex ubi venit necessitas) ${ }^{48}$. Às vezes, no entanto, a necessidade cria leis ao fundamentar obrigações e deveres legais. Esta circunstância reflete-se no conhecido aforismo francês legal: nécessité oblige. Assim, a necessidade torna-se uma importante fonte de direito, isto é, de obrigatoriedade legal. Estou usando o conceito de necessidade dessa maneira, embora as duas implicações legais estejam interligadas. Se a necessidade pode levar à suspensão

43 Nesse sentido, veja Anne Peters, "Humanidade como $A$ e $\Omega$ da Soberania", no European Journal of International Law 20 (2009): 513-544; e Anne Peters, "Estamos nos movendo para a constitucionalização da comunidade mundial?" em Antonio Cassese, ed., Percebendo a Utopia: O Futuro do Direito Internacional (Oxford, Nova York: Oxford University Press, 2012), 118-135, em 120-123. Peters considera a mudança de paradigma da soberania para a humanidade e considera a humanidade como o princípio fundamental do direito público. A humanidade está subjacente a todo o sistema internacional de proteção dos direitos humanos. Veja também a "abordagem constitucionalista da sociedade" de Gunther Teubner, Fragmentos Constitucionais: Constitucionalismo Social e Globalização (Oxford, Nova York: Oxford University Press, 2012); e Mattias Kumm, "A virada cosmopolita no constitucionalismo: uma concepção integrada do direito público", Indiana Journal of Global Legal Studies 20 (2013): 605-628. Kumm argumenta que todos os estados-nação legítimos devem ser estados cosmopolitas no sentido de incorporar e refletir as condições de legitimidade global para reivindicações de soberania em suas próprias constituições.

44 Sobre esse assunto, veja Domingo, "The Global Human Community".

45 Cf. Horace, The Odes 1.35.17-20, ed., Niall Rudd, Loeb Classical Library (Cambridge MA: Harvard University Press, 2004): A maioria das tarefas precisas à sua frente, transportando feixe de luz, pregos e cunhas em sua mão de bronze, não esquecendo o grampo imóvel e chumbo para derreter].

46 Cf. A. Wagner, "Necessitas", em Wilhelm Heinrich Roscher, ed., Ausführliches Lexikon der griechischen e römischen Mythologie III.1 (Leipzig: B.G. Teubner, 1902), cols. 70-72.

47 Cf. Black Law Dictionary, ed., Bryan A. Garner (St. Paul, MN: West Group, 1999), 1053.

48 Para um comentário sobre esta regra e outras regras similares, ver Rafael Domingo, org., Principios de Derecho Global, 3. ed. (Cizur Menor: Thomson Aranzadi, 2006), no. 146. 
das leis, ela também deve ser capaz de sugerir novas leis. Caso contrário, a sociedade se dissolveria no caos. Não é mera coincidência que a formulação da mais famosa definição de obrigação, dos Institutos de Justiniano ${ }^{49}$, inclua a palavra "necessidade". Nesse contexto, a necessidade expressa a ideia de que a obrigação criada por um vínculo legal restringe os desejos do partido. Esta definição de obrigação entrou na tradição do direito comum anglo-americano por meio do trabalho de Henry de Bracton (c. 1210-68), De legibus et consuetudinibus Angliae ${ }^{50}$. O jurista romano Modestino, em seu primeiro livro de regras legais, expressou muito bem o que estou tentando explicar aqui: "Assim, toda lei foi feita ou por consentimento, ou estabelecida por necessidade, ou confirmada pelo costume ${ }^{\prime 51}$, o termo necessidade tem seu significado comum, não técnico: uma necessidade ou desejo imperativo, uma pressão de circunstâncias, uma compulsão física ou moral, que desculpa alguém de cumprir uma obrigação ou criar uma nova. ${ }^{52}$

Em nossos dias, um forte senso de contratualismo alimentou o desrespeito pela divisão das fontes da lei no consentimento, no costume e na necessidade. O consentimento tornou-se primário, enquanto o costume e a necessidade são relegados à irrelevância. O costume, no entanto, conseguiu manter seu status (reconhecidamente secundário) no âmbito internacional graças à própria natureza do direito internacional ${ }^{53}$ e graças, em parte, à defesa do direito internacional consuetudinário por parte de alguns estudiosos internacionais nos últimos $a_{n o s}{ }^{54}$. Mas o constitucionalismo global ainda precisa recuperar o conceito

49 Institutos de Justiniano 3.13 pr. ed. Paul Krüger, Instituições. Corpus luris Civilis, vol. Eu, 16a ed. (Berlin: Weidmann, 1954): "obligatio est iuris vínculo, quo necessita adstringimur alicuius solvendae rei secundum nostrae civitatis iura" [Uma obrigação é uma obrigação legal pela qual somos obrigados pela necessidade de realizar algum ato de acordo com as leis de nossa comunidade].

50 Institutos de Justiniano 3.13 pr. ed. Paul Krüger, Instituições. Corpus luris Civilis, vol. Eu, 16a ed. (Berlin: Weidmann, 1954): "obligatio est iuris vínculo, quo necessita adstringimur alicuius solvendae rei secundum nostrae civitatis iura" [Uma obrigação é uma obrigação legal pela qual somos obrigados pela necessidade de realizar algum ato de acordo com as leis de nossa comunidade].

51 Henry de Bracton, De legibus e consuetudinibus Angliae (sobre a lei e costumes da Inglaterra), ed. George E. Woodbine e Samuel E. Thorne, Selden Society, vol. 2 (Cambridge, MA: Harvard University Press, 1968), 283: Et sciendum quod obligatio est iuris $v$ vrcle quo necessita adstringimur ad aliquid dandum vel faciendum [Uma obrigação é um vínculo jurídico pelo qual somos constrangidos pela necessidade (quer desejemos ser ou não), para dar ou fazer alguma coisa].

52 Modestinus, Digest 1.3.40, ed. Alan Watson, The Digest de Justiniano, Filadélfia: University of Pennsylvania Press, 1985).

53 De fato, nos casos em que é difícil conseguir um acordo entre os estados, o costume pode desempenhar um papel importante. Para esta e outras áreas em que o direito consuetudinário é desenvolvido, ver Antonio Cassese, International Law, 2nd ed. (Oxford: Oxford University Press, 2005), 166.

54 Cf. Brian D. Lepard, Direito Internacional Consuetudinário: Uma Nova Teoria com Aplicações Práticas (Nova York, Cambridge: Cambridge University Press, 2010); David J. Bederman, Custom como fonte de direito (Nova York, Cambridge: Cambridge University Press, 2010). 
de necessidade para desenvolver uma abordagem correta da lei nesta era da globalização. Como Tony Honoré apropriadamente coloca: "No que diz respeito à comunidade mundial, a necessidade é o terreno relevante. ${ }^{55 "} \mathrm{~A}$ razão para aterrar a comunidade mundial em necessidade já foi explicada no século XVI por Francisco de Vitoria usando o pensamento aristotélico: causas necessárias são causas finais ${ }^{56}$. De fato, as relações humanas em uma era de globalização tornaram necessário que a humanidade gerencie bem suas necessidades globais. Algumas dessas necessidades derivam diretamente da dignidade humana (por exemplo, erradicar a pobreza e combater o terrorismo internacional). O constitucionalismo global provoca a questão premente da legitimidade da governança global ${ }^{57}$, e o princípio da necessidade oferece uma boa resposta.

As normas especiais de ius cogens e erga omnes ${ }^{58}$, que em nossos dias adquiriram maior relevância prática, constituem uma poderosa expressão da atual recuperação do princípio da necessidade. O caráter peremptório dos ius cogens e a existência de normas que todos os estados podem invocar em caso de violação (erga omnes) podem sugerir a necessidade de algumas normas e padrões para que o sistema do próprio direito internacional sobreviva. De fato, a ordem jurídica internacional não poderia ser um sistema universal se fosse fundada apenas no princípio do consensualismo. Se uma determinada comunidade política não consentisse com o sistema universal de regras, o direito internacional deixaria de ser universal. É precisamente o princípio da necessidade que torna o direito internacional universal (lei global), protegendo alguns valores morais irrevogáveis (ius cogens) e expandindo seu escopo (erga omnes norms).

2.7. Uma abordagem não fundacional do poder constituinte. A lei romana ajuda a esclarecer que o que é realmente fundamental para o constitucionalismo global é a comunidade política de cidadãos livres ${ }^{59}$, não o poder constituinte ou a

55 Tony Honoré, "A Comunidade Humana e Regra da Maioria” (1978), em Tony Honoré, Making Law Bind: Ensaios Legais e Filosóficos (Oxford: Clarendon Press, 1987), 237.

56 Cf. Francisco de Vitoria, Sobre o Poder Civil, pergunta 1, artigo 1, seções 3-6, ed. Anthony Pagden e Jeremy Lawrence, Francisco de Vitória, Political Writings (Cambridge: Cambridge University Press, 1991), pp. 6-10.

57 Nesse sentido, ver Anne Peters, "Conclusão", em Jan Klabbers, Anne Peters, e Geir Ulfstein, editores, The Constitutionalization of International Law (Oxford, Nova York: Oxford University Press, 2010), 351.

58 Para uma visão geral, veja Malcolm N. Shaw, International Law, 6th ed. (Cambridge, Nova York: Cambridge University Press, 2014), 123-128, 178-179; e Robert Kolb, Théorie du ius cogens international: Essai de releitura do conceito (Geneva: Graduate Institute, 2001).

59 Nesse sentido, ver Mattias Kumm, "Poder Constitutivo, Constitucionalismo Cosmopolita e Direito Pós-Positivista", International Journal of Constitutional Law 14 (2016): 697-711. 
constituição como tal ${ }^{60}$. O Senado e o Povo de Roma (Senatus Populusque Romanus), que incorporavam o poder político da República Romana, pressupunham a própria ideia de povo. Foram as pessoas (os cidadãos do passado e do presente) que finalmente deram legitimidade à constituição romana, e não o contrário.

A ideia do poder constituinte, no entanto, é moderna, pelo menos na forma em que surgiu com a criação do Estado-nação. O poder constituinte foi associado ao constitucionalismo por meio da interpretação calvinista do poder soberano e foi transformado durante o Iluminismo europeu como resultado da racionalização secular ${ }^{61}$. O conceito de poder constituinte pressupõe não apenas a crença de que o poder político se baseia, em última análise, no povo ou na comunidade política, mas também a compreensão de que a constituição política deriva seu poder e legitimidade do povo. A comunidade política torna-se assim a fonte última do poder constituinte que legitima a autoridade das constituições.

Na dimensão jurídica global, no entanto, o conceito de poder constituinte deve ser reformulado. Caso contrário, a comunidade global correria o risco de ser transformada em um estado global. Essa transformação em um estado global seria, nas palavras de Hannah Arendt, "o fim de toda a vida política como a conhecemos" 62 , o fim da própria liberdade. A comunidade global é uma comunidade de muitos povos e, como tal, não constitui um único povo. Um povo é uma pluralidade de pessoas reconhecidas como um todo. A comunidade global, no entanto, não compreende apenas uma pluralidade da população mundial, mas é sua totalidade. A ideia de um povo exige alteridade - esse povo está em oposição a outras pessoas. Porque a comunidade global é única em sua totalidade, é incompatível com a alteridade. Assim, a comunidade global não exige um poder constituinte no sentido moderno da expressão "Nós, o Povo de [algum estado ou território]". Não há "Nós, a Humanidade" e, portanto, não pode haver constituição formal escrita. Em seu relato revisado

60 Para uma boa visão geral, ver Martin Loughlin, Fundações do Direito Público (Oxford, Nova York: Oxford University Press, 2010), 221-228; e Martin Loughlin, "O Conceito de Poder Constituinte", Jornal Europeu de Teoria Política 13.2 (2014): 218-237. Veja também Ernst Wolfgang Böckenförde, "O Poder Constituinte do Povo: Um Conceito Liminal de Direito Constitucional”, em Ernst Wolfgang Böckenförde, Teoria Constitucional e Política. Selected Writings, ed., Mirjam Künkler e Tine Stein (Oxford, Nova York: Oxford University Press, 2017), pp. 169-185.

61 Loughlin, "O Conceito de Poder Constituinte", esp. em 219.

62 Hannah Arendt, "Karl Jaspers: Cidadão do Mundo", em Hannah Arendt, Homens em Tempos Obscuros (San Diego, Nova York, Londres: A Harvest Book, Harcourt Brace \& Company, 1995), 81. 
do poder constituinte sob a perspectiva do constitucionalismo global, Mattias Kumm argumenta que o poder constituinte é investido não apenas em "Nós, o Povo", mas também na "comunidade internacional" como uma exigência de uma concepção cosmopolita e pós-positivista do constitucionalismo ${ }^{63}$. Os dois componentes, "Nós, o Povo" e a "comunidade internacional", seriam "coconstituintes" das constituições nacionais e da comunidade internacional. Este co-princípio do poder constituinte assegura a integração das constituições nacionais na ordem global. Kumm, portanto, desafia a abordagem positivista que tradicionalmente atribuía ao poder constituinte um papel fundamental, e ele defende uma abordagem normativamente constituída e circunscrita.

Concordo basicamente com Kumm, mas diferem na formulação do argumento. Na minha opinião, por causa da globalização e do surgimento (por necessidade) de uma comunidade global, o poder constituinte de uma comunidade política não é mais investido em "Nós, o Povo", mas em "Nós, um povo da comunidade global". As pessoas não são mais uma comunidade política independente, mas uma comunidade interdependente com o resto da população mundial. Uma comunidade política é, portanto, sempre uma expressão e uma parte da comunidade global. A comunidade global não requer um poder constituinte global autônomo, porque não é uma comunidade completa ${ }^{64}$. Em última análise, a razão pela qual tanto a comunidade política quanto a comunidade global são o poder constituinte de qualquer comunidade em particular e, ao mesmo tempo, não há poder constituinte global, é que a comunidade global consiste de uma comunidade incompleta, mas necessária. Eu chamo de completa aquelas comunidades que, informadas pelo princípio de autonomia e autogoverno, se esforçam para satisfazer o máximo possível de necessidades humanas dentro de suas fronteiras (trabalho, saúde, educação, segurança e assim por diante). Em contraste, sociedades incompletas são aquelas que se esforçam para satisfazer apenas certas necessidades humanas específicas.

63 Kumm, "Poder Constituinte, Constitucionalismo Cosmopolita e Lei Pós-Positivista", em 698. Veja a resposta de Neil Walker, "O Retorno do Poder Constituinte: Uma Resposta a Mattias Kumm", International Journal of Constitutional Law 14 (2016): 906-913 e a réplica de Kumm, "Constituinte de poder, limites e identidade: na profundidade justificatória do constitucionalismo. Uma réplica para Neil Walker, International Journal of Constitutional Law 14 (2016): 914-924.

64 Eu desenvolvo este argumento da comunidade global como comunidade incompleta em Domingo, "A Comunidade Humana Global". 
Aristóteles e Aquino consideravam a polis ${ }^{65}$ ou civitas $^{66}$ como a única comunidade completa e autossuficiente. Em nossos dias, o estado-nação é o paradigma de uma comunidade completa. Além de ser completo nesse sentido, o Estado-nação é também uma sociedade instrumental: não é necessário, na medida em que seu propósito não é natural e suas responsabilidades podem ser realizadas por outros grupos políticos e sociais intermediários. Da mesma maneira que a Bélgica, o Japão ou os Estados Unidos começaram a existir em um momento histórico concreto, eles também podem deixar de existir. Essas comunidades não são um requisito insubstituível para a existência humana. Eles são um produto cultural da experiência humana e do desenvolvimento histórico. A rica variedade de comunidades políticas existentes é mutável, na medida em que estão sujeitas a vicissitudes políticas. Nessas comunidades políticas, a ciência dos possíveis reinos; isto é, essas entidades não têm um valor intrínseco tanto quanto um instrumental. Eles não são fins em si mesmos, uma vez que são instrumentais e políticos por natureza.

A comunidade global tornou-se agora uma condição necessária, mas não suficiente para qualquer poder constituinte de qualquer povo que seja um subconjunto da humanidade organizado como uma comunidade política completa. Em outras palavras, o autogoverno de qualquer comunidade política ou povo deve ser visto dentro da estrutura da lei global para ser globalmente legitimado. A consequência prática desse insight é que a lei global não deve depender do consentimento do Estado, como aconteceu com o direito internacional clássico. A lei global deve ter a mesma legitimidade na comunidade global que a lei nacional tem na comunidade nacional. Nesse sentido, uma abordagem pós-positivista (ver próxima seção, 2.8) é necessária, uma vez que qualquer comunidade política influencia a comunidade global, e a comunidade global influencia a comunidade nacional. Nessa perspectiva, nenhum sistema jurídico em um mundo globalizado consistiria apenas em normas e regulamentos comandados por um único soberano. Se isto é assim, a ideia de poder constituinte deve ser estendida e não rigidamente restringida ao poder nacional. Isso não significa, no entanto, que um poder constituinte global deva ser reconhecido.

65 Aristóteles, Política 1.1.1252a, ed. e transl. H. Rackham (Cambridge MA, Londres: Harvard University Press, 1990).

66 Cf. Tomás de Aquino, Summa Theologiae I-II, q. 90 a. 3 ad 3; Summa Theologiae II - II, q. 65 a. 2 ad 2, e Sententia libri Politicorum 1.1.23 (ed. Enrique Alarcón, Corpus Thomisticum, Universidade de Navarra, 2000, em linha: www. corpusthomisticum.org). Para mais informações sobre o conceito de "communitas perfecta" em Tomás de Aquino, ver John Finnis, Aquino: Teoria Moral, Política e Jurídica (Oxford, Nova York: Oxford University Press, 1998), 52, 114, $122,219,2211$ n. 10, 226 e 307. 
2.8. Uma abordagem não positivista da lei. A lei romana oferece uma abordagem pré-positivista da lei e impede que o constitucionalismo global assuma uma posição positivista implícita ou explícita. O termo lei positiva (ius positivum) não é uma criação romana, mas medieval. A distinção entre lei positiva e lei natural foi proposta pela primeira vez por estudiosos franceses, como William of Conches, Hugh de Saint Victor e Peter Abelard, bem como canonistas franceses do século $\mathrm{XII}{ }^{67}$. Isso não significa que a lei romana não consista em lei positiva: a lei civil romana, a lei pretoriana e a lei romana das nações certamente podem ser categorizadas pelo termo não romano "lei positiva". Nas palavras de um dos grandes positivistas, Hans Kelsen, "o positivismo se confina a uma teoria do direito positivo e sua interpretação"68. Assim, o positivismo está completamente fora do direito romano, que oferece uma estrutura integrada às diferentes dimensões da lei: lei das nações, lei fetal, lei sagrada, direito pretoriano e direito civil, entre outros.

O constitucionalismo global deve reconhecer a relevância do direito positivo, mas o direito positivo deve cumprir sua função como parte de uma estrutura cosmopolita e pós-positivista ${ }^{69}$. O constitucionalismo global não pode ser positivista, porque não pode estar firmemente conectado aos postulados mais relevantes do positivismo. Ao contrário do positivismo, o constitucionalismo global exige que a autoridade legislativa soberana possa estar sujeita a limitações legítimas. Ao contrário do positivismo, o constitucionalismo global defende restrições internas de poderes constituintes que não podem ser fornecidos apenas apelando para a vontade do povo. Ao contrário do positivismo, o constitucionalismo global exige que os padrões normativos globais não possam ser criados a partir do nada, baseados apenas em um ato soberano de vontade popular. Ao contrário do positivismo, o constitucionalismo global não deve confundir a lei global e a legalidade global. Ao contrário do positivismo, o constitucionalismo global não deveria exigir uma norma básica como razão de validade, mas alguns princípios, valores, instituições e padrões deveriam ser usados como parâmetros para inspirar a nova lei pública global.

67 Ver Sten Gagnér, Studien zur Iddeengeschichte der Gesetzgebung (Estocolmo: Almqvist \& Wiksell, 1960), 210240; e de Luscombe e GR Evans, "O Renascimento do Século XII", em James Henderson Burns, org., A História de Cambridge do Pensamento Político Medieval (c.350-c.1450) (Cambridge Nova York: Cambridge University Press; 1988), 306-338, em 336.

68 Hans Kelsen, Teoria Geral do Direito e do Estado, trad. Andres Wedberg (Cambridge MA: Harvard University Press, 1945), 391.

69 Kumm, "Poder Constitutivo, Constitucionalismo Cosmopolita e Lei Pós-Positivista", 698. 
O constitucionalismo global deve transcender o positivismo em vez de rejeitar todas as ideias e suposições positivistas. Como os pós-positivistas aceitam que as teorias, o conhecimento e os valores de um pesquisador podem influenciar o que é observado ${ }^{70}$, o constitucionalismo global afirma que qualquer comportamento de uma comunidade política afeta a comunidade global, e qualquer comportamento da comunidade global afeta a comunidade em particular. A comunidade global e a comunidade nacional são observadoras e observaram realidades constitucionais. O constitucionalismo global nos permite ver o estado não apenas de dentro, mas também de fora. Isso explica por que a interdependência está no coração do constitucionalismo global ${ }^{71}$. A proteção dos direitos humanos, por exemplo, é crítica tanto no direito internacional quanto nacional. Se os direitos humanos não estiverem bem protegidos nos tribunais nacionais, os tribunais internacionais estarão disponíveis para analisar as violações. Mas se os tribunais internacionais violarem a lei internacional dos direitos humanos, os tribunais nacionais não precisam cumprir suas decisões. Nesses casos, como bem argumentou Geir Ulfstein, o valor constitucional da proteção dos direitos humanos deve prevalecer sobre a importância de se respeitar as decisões judiciais dos tribunais internacionais. ${ }^{72}$

2.9. Centralidade de litígios e pluralidade de jurisdições. A história dos procedimentos legais romanos é muito menos que a história do próprio sistema legal. Os recursos legais e o litígio em geral influenciaram tanto a estrutura e a evolução do direito romano que o direito substantivo só pode ser entendido a partir dessa perspectiva processual. Osjuristas romanos estavam mais preocupados com remédios legais específicos do que com direitos abstratos. Por essa razão, a lei romana é por natureza uma lei de ações. A ligação entre o período clássico e o procedimento legal é tão forte que o período clássico terminou junto com o desvanecimento do chamado procedimento de formulário em torno de 230

70 A conexão entre o pós-positivismo e a física quântica é óbvia. A teoria quântica afirma que, pelo próprio ato de observar, o observador afeta a realidade observada. Para uma visão geral da física quântica, ver, entre outros, Kenneth W. Ford e Diane Goldstein, O mundo quântico: física quântica para todos (Cambridge MA, Londres: Harvard University Press, 2005).

71 Nesse sentido, também podemos entender o constitucionalismo compensatório, ao qual Anne Peters se refere. Veja Anne Peters, "Constitucionalismo Compensatório: A Função e o Potencial das Normas e Estruturas Internacionais Fundamentais", Leiden Journal of International Law 19 (2006): 579-610.

72 Nesse sentido, ver Ulfstein, "O Judiciário Internacional", 152. Ver também Andreas Føllesdal, Johan Karlsson Schaffer, Geir Ulfstein, A Legitimidade dos Regimes Internacionais de Direitos Humanos: Llegal, Perspectivas Políticas e Filosóficas (Cambridge, Nova York: Cambridge University Press 2014). 
E.C. O pretor era o magistrado jurisdicional por excelência. A chave para o direito pretoriano residia no fato de que o pretor controlava os remédios, e sua principal função legal era conceder remédios em casos individuais. Se ambas as partes eram cidadãos romanos, o magistrado com jurisdição dentro dos limites de Roma era o pretor urbano. Se um ou os dois litigantes não eram cidadãos romanos, o magistrado jurisdicional era o praetor peregrinus. $\mathrm{O}$ crescimento do comércio internacional levou os romanos a reconhecer algumas instituições e transações (por exemplo, contratos de vendas, serviços e empréstimos) que poderiam ser aplicadas pelos tribunais romanos às relações entre estrangeiros e entre estrangeiros e cidadãos (ius gentium). Os aediles curules tinham poder jurisdicional sobre as vendas concluídas no mercado de Roma. Um tribunal especial tinha jurisdição onde algumas heranças relevantes eram reivindicadas ou a validade de um testamento era contestada. Alguns casos de maior interesse público ficaram sob a jurisdição de um tribunal de vários juízes chamados recuperatores. Nas províncias, o governador tinha jurisdição e desempenhava o papel de pretor. Os magistrados locais deveriam exibir e administrar a justiça de acordo com o edital do governador da província. Nos municípios italianos, os magistrados locais tinham uma jurisdição limitada, e era possível que as partes exigissem a transferência do procedimento para Roma. Por acordo voluntário e formal (compromissum), a lei romana também permitia que as partes submetessem uma disputa à arbitragem. A execução da sentença veio das estipulações recíprocas dadas pelos litigantes e foi reforçada pelas penalidades como parte adicional do acordo. A vantagem da arbitragem era que o árbitro tinha mais liberdade para determinar uma sentença do que o juiz do procedimento do formulário, que sempre estava vinculado às instruções do pretor inseridas na fórmula. Este esboço básico do procedimento legal mostra a grande flexibilidade da ordem jurídica romana devido à pluralidade de jurisdições inter-relacionadas sob o mesmo sistema legal.

Uma característica relevante do direito internacional atual, e uma expressão clara de sua constitucionalização, é a crescente importância e o estabelecimento de tribunais internacionais e a judicialização da solução de controvérsias. ${ }^{73}$ Nas últimas décadas, novos tribunais, como o Tribunal Internacional do Direito do Mar, o órgão de solução de controvérsias da Organização Mundial do Comércio e a arbitragem do Centro Internacional para Arbitragem de Disputas sobre Investimentos (ICSID), entre outros, foram criados. Como resultado, áreas relevantes do direito, como

73 Veja Ulfstein, "The International Judiciary", 126-152. 
o direito comercial internacional e o direito do mar, são submetidas ao controle judicial internacional. Esses tribunais se misturam e interferem nas ações do Estado nacional enquanto desenvolvem funções constitucionais além do Estado. O constitucionalismo global deve continuar expandindo um sistema de pluralismo jurisdicional que dificulta, restringe e impede a concentração excessiva de autoridade judicial, sem ter medo de uma fragmentação razoável. O direito romano oferece ao constitucionalismo global um bom exemplo de pluralismo jurídico e jurisdicional. Fronteiras territoriais não podem resolver todos os conflitos legais.

2.10. Uma lei prática relacionada com a realidade. Os juristas romanos cultivavam uma ciência legal sofisticada e prática e produziam uma literatura substancial no campo do direito: comentários sobre o direito civil e sobre o decreto pretoriano, coleções de opiniões legais ou distinções legais, monografias sobre temas legais e assim por diante. Mas, diferentemente dos gregos, os juristas romanos dedicaram pouco tempo a abstrações filosóficas. ${ }^{74}$ Eles estavam preocupados principalmente em encontrar soluções justas em casos individuais. Seu interesse por questões filosóficas era periférico. Eles não desenvolveram uma teoria geral de justiça, lei, estado ou administração política. Eles simplesmente acomodaram a filosofia grega quando necessário para seus propósitos legais. Os juristas romanos estavam preocupados com a prática diária da lei, provavelmente porque a maioria deles eram homens públicos envolvidos na política e estavam interessados em questões legais (sem qualquer remuneração) apenas como parte de suas carreiras políticas. O desenvolvimento da ciência jurídica era uma questão de disputa sobre interpretações do direito, e a ciência jurídica estava muito ligada a conflitos legais autênticos.

O constitucionalismo global é defendido e desenvolvido principalmente pelos acadêmicos e, em certa medida, pelos tribunais internacionais, mas não pelos governos nacionais, pelos formuladores de tratados e pelos poderosos atores internacionais. ${ }^{75}$ Assim, o constitucionalismo corre o risco de isolar-se, criando o

74 Sobre o caráter dos juristas romanos, ver Fritz Schultz, Uma História da Ciência Jurídica Romana (Oxford: Clarendon Press, 1946); Richard A. Bauman, advogados na política de transição romana: um estudo dos juristas romanos em seu cenário político no final da República e Triunvirato (Munique: Beck Verlag, 1985); Bruce W. Frier, A ascensão dos juristas romanos: Estudos em Pro Caecina de Cícero (Princeton, NJ: Princeton University Press, 1985); Tony Honoré, Imperadores e Advogados, 2. ed. (Oxford, New York: Oxford University Press, 1994); Wolfgang Kunkel, Die Römischen Juristen. Herkunft und soziale Stellung, 2. ed. Reimpressão (Colônia: Bohlau Verlag, 2001).

75 Nesse sentido, ver Peters, "Estamos nos movendo para a constitucionalização da comunidade mundial?" Em 118 e 128. 


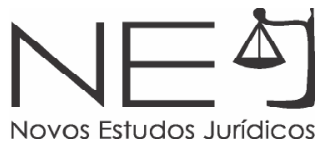

seu próprio discurso desconectado da realidade jurídica ou, como assinalou Anne Peters, o risco de promover um governo de juízes "no qual o auto empoderamento judicial é alcançado com a ajuda da constitucionalidade da língua." ${ }^{176}$ Este perigo é real. A lei romana oferece ao constitucionalismo global um bom exemplo de desenvolvimento de uma ciência jurídica prática elaborada a partir de conflitos legais e não de abstrações jurídicas. O constitucionalismo global não deve ser apenas um produto intelectual e infértil. Deveria ser, ao contrário, um modo de pensar que ilumina todo o corpo do direito internacional na era da globalização.

\section{CONSIDERAÇÕES FINAIS}

A lei romana oferece boas lições de como os sistemas, doutrinas e paradigmas jurídicos podem ser desenvolvidos e modernizados com base em ideias e princípios equitativos. É, portanto, uma fonte lucrativa de inspiração para o constitucionalismo global emergente. O espírito cosmopolita do direito romano, sua constituição não escrita, seu respeito pela tradição e seu pluralismo jurídico estão entre as características do sistema de direito romano que podem ajudar a desenvolver uma constitucionalização coerente do direito internacional. Mas o elo mais importante entre o direito romano e o constitucionalismo global é que, embora a lei romana oferecesse um arcabouço prestatista, pré-soberano, prénacionalista e pré-positivista, o constitucionalismo global oferece uma estrutura pós-soberanista, pós-nacionalista e pós-positivista. A lei romana constitui um excelente antídoto para o excesso de elementos estatistas, positivistas e soberanos na elaboração e no desenvolvimento do constitucionalismo global.

\section{REFERÊNCIAS DAS FONTES CITADAS}

PETERS, Anne Peters. Constitucionalismo Global. Em Michael T Gibbons, ed., A Enciclopédia do Pensamento Político (Malden: John Wiley and Son, 2015) disponível em: http://www.mpil.de/files/ pdf4/Peters_Global_Constitutionalism3.pdf.

DUNOFF, Jeffrey L.; TRACHTMAN, Joel P.; eds., Governando o mundo? Constitucionalismo, Direito Internacional e Governança Global. Nova York, Cambridge: Cambridge University Press, 2009.

Jan Klabbers, Anne Peters e Geir Ulfstein, A constitucionalização do direito internacional (Oxford, Nova York: Oxford University Press, 2010); Surendra Bhandari, Constitucionalismo Global e o Caminho do Direito Internacional (Leiden, Boston: Brill Nijhoff, Leiden, 2016). 
Anthony F. Lang Jr. e Antje Wiener, editores, Handbook on Global Constitutionalism (Cheltenham e Northampton, MA: Edward Elgar Publishing, 2017).

Takao Suami, Mattias Kumm, Anne Peters e Dimitri Vanoverbeke, Constitucionalismo Global de Perspectivas Européias e do Leste Asiático (Cambridge, Nova York: Cambridge University Press, 2018).

David J. Bederman, A Fundação Clássica da Constituição Americana (Cambridge e Nova York: Cambridge University Press, 2008).

Harold James, The Roman Predicament: Como as Regras da Ordem Internacional Criam a Política do Império (Princeton, NJ: Princeton University Press, 2006), esp. p. 141

Neil Walker, Intimations of Global Law (Cambridge, Nova York: Cambridge University Press, 2015). Veja também Rafael Domingo, A Nova Lei Global (Cambridge, Nova York: Cambridge University Press, 2010).

David Johnston, ed., The Cambridge Companion to Roman Law (Cambridge, Nova York: Cambridge University Press, 2015).

Paul de Plessis, Clifford Ando e Kaius Tuori, The Oxford Handbook of Roman Law and Society (Oxford: Oxford University Press, 2017).

Rafael Domingo, Lei Romana: Uma Introdução (London, New York: Routledge, 2018).

FranzWieacker, Römische Rechtgeschichte:Quellenkunde, Rechtsbildung, Jurisprudenze Rechtsliteratur I (Munique: Beck Verlag, 1988).

Benedict Kingsbury e Benjamin Straumann, orgs., The Roman Foundations of the Law of Nations: Alberico Gentili e Justice of Empire (Oxford e New York: Oxford University Press, 2010).

Benjamin Straumann, Direito Romano no Estado da Natureza: os fundamentos clássicos do direito natural de Hugo Grotius (Nova York e Cambridge: Cambridge University Press, 2015).

Randall Lesaffer, "Argumento do Direito Romano no Direito Internacional Atual: Prescrição Ocupacional e Aquisitiva", no European Journal of International Law 16 (2005): 25-58.

Ronald Syme, A Revolução Romana (Oxford, Nova York: Oxford University Press, reimpressão de 2002).

Benjamin Straumann, Crise e Constitucionalismo: Pensamento Político Romano da Queda da República à Era da Revolução (Oxford, Nova York: Oxford University Press, 2016).

Rafael Domingo, "A Comunidade Humana Global", Chicago Journal of International Law 13.1 (2012): 563-587.

Thomas Pangle, "cosmopolitismo romano. Os estóicos e Cícero, "em Lee Trepanier e Khalil M. Habib, ed., Cosmopolitanism na Era da Globalização (Lexington: The University Press de Kentucky, 2011) 40-69. 
Martha C. Nussbaum, “Kant e cosmopolitismo estoico”, no Journal of Political Philosophy 5.1 (1997): 1-25. Anthony Padgen, "Estoicismo, Cosmopolitismo e o Legado do Imperialismo Europeu", Constellations 7.1 (2000): 1-22.

Tony Honoré, Ulpian: Pioneiro dos Direitos Humanos, 2a ed. (Oxford e Nova York: Oxford University Press, 2002).

Pauline Kleingeld e Eric Brown, "Cosmopolitanism", em Edward N. Zalta, ed., A Enciclopédia de Stanford de Filosofia (Outono de 2014 Edition), URL = <https://plato.stanford.edu/archives/ fall2014 / entradas / cosmopolitismo />.

Seyla Benhabib, ed., Another Cosmopolitanism (Oxford, Nova York: Oxford University Press, 2006).

Mattias Kumm, "A virada cosmopolita no constitucionalismo: uma concepção integrada do direito público", Indiana Journal of Global Legal Studies 20 (2013): 605-628.

Rafael Domingo, "Gaius, Vattel, e o Novo Paradigma Global da Lei", European Journal of International Law 22.3 (2011): 627-647;

Wolfgang Kunkel, Uma Introdução à História Jurídica e Constitucional Romana, 2a ed., Trad. por J. M. Kelly (Oxford: Clarendon Press, 1973)

Andrew Lintott, A Constituição da República Romana (Oxford e Nova York: Oxford University Press, 1999).

Benjamin Straumann, Crise e Constitucionalismo: Pensamento Político Romano da Queda da República à Era da Revolução (Oxford e Nova York: Oxford University Press, 2016).

Cicero, On the Commonwealth 1.70, ed. James E. G. Zetzel (Cambridge: Cambridge University Press, 1999).

Polybius, The Histories 1.1.5, ed. F. W. Walbank, Christian Habicht, e W. R. Paton, Loeb Classical Library, vol. 1 (Cambridge, MA: Harvard University Press, 2010).

Políbio, As Histórias 6.5.11-18, ed. Walbank, et al., Vol. 3; e Cicero On the Commonwealth 1.69, ed. James E. G. Zetzel (Cambridge: Cambridge University Press, 1999).

Mitj Sadek, "Cícero e a Constituição Mista (res publica mixta)," Keria: Studia Latina e Graeca 11/2 (2009): $29-41$.

Jed W. Atkins, Pensamento Político Romano (Cambridge, Nova York: Cambridge University Press, 2018), 11-36.

Martti Koskenniemi, “Direito Internacional na Europa: Entre Tradição e Renovação”, European Journal of International Law 16 (2005): 113-124. 
Bernhard Kübler, "Maiestas", em agosto Friedrich Pauly e George Wissova, editores, Paulys Realencyclopädie der classischen Altertumswissenschaft: Lysimichos bit Mantike, vol. 14.1 (Stuttgart, Munique: Alfred Druckenmüller 1928), cols. 452-459.

R. A. Bauman, The Crimen Maiestatis na República Romana e Principado de Augustan (Joanesburgo: Witwatersrand University Press, 1970).

Rafael Domingo, Auctoritas (Barcelona: Ariel, 1999), 23-25;

Álvaro Jacobo Pérez, Auctoritas et maiestas. História, programa e iconografía na moneda de Vespasiano (São Vicente do Rasgo: Publicaciones da Universidade de Alicante, 2003).

Davide Salvo, "Maiestas", em Roger S. Bagnall, Kai Brodersen, Craige B. Champion, Andrew Erskine e Sabine R. Huebner, editores, A Enciclopédia da História Antiga (Malden, MA: Blackwell Publishing, 2013), 4236-4238, com bibliografia em 4238.

Francesco Calasso, I glossatori et la teoria della sovranità, 3a ed. (Milan: Giuffrè, 1957). A teoria, no entanto, precisa de revisão

Jean Bodin, Les seis libras da República, vol. 1 (Paris: Librairie Arthème Fayard, 1986), 179.

Howell A. Lloyd, Jean Bodin, "Este homem eminente da França. Uma biografia intelectual (Oxford, Nova York: Oxford University Press, 2017).

Daniel Lee, Soberania Popular no Pensamento Constitucional Moderna Inicial Oxford, Nova York: Oxford University Press, 2016).

Ulpian, Digest 1.3.31, ed. Alan Watson, The Digest de Justiniano (Filadélfia: University of Pennsylvania Press, 1985).

Jean L. Cohen, Globalization and Sovereignty (Nova York, Cambridge: Cambridge University Press, 2012).

Martti Koskenniemi, "Direito Internacional no Mundo das Idéias", em James Crawford e Martti Koskenniemi, ed., Direito Internacional (Cambridge, Nova York: Cambridge University Press, 2012), 58

Papinian, Digest 2.14.38, ed. Alan Watson, The Digest de Justiniano (Filadélfia: University of Pennsylvania Press, 1985).

Cicero, On Invention 1, 68. ed. H. M. Hubbell, Loeb Classical Library (Cambridge, MA: Harvard University Press, 1949).

Martin Loughlin, The Idea of Public Law (Oxford: Oxford University Press, 2003), e Martin Loughlin, Fundações do Direito Público (Oxford, Nova York: Oxford University Press, 2010).

Léon Duguit, Lei no Estado Moderno, trad. por Frida e Harold Laski (Nova York: B. W. Huebsch, 1919), 32. 
Anne Peters, "Humanidade como A e $\Omega$ da Soberania", no European Journal of International Law 20 (2009): 513-544;

Anne Peters, "Estamos nos movendo para a constitucionalização da comunidade mundial?" em Antonio Cassese, ed., Percebendo a Utopia: O Futuro do Direito Internacional (Oxford, Nova York: Oxford University Press, 2012), 118-135, em 120-123.

"Abordagem constitucionalista da sociedade" de Gunther Teubner, Fragmentos Constitucionais: Constitucionalismo Social e Globalização (Oxford, Nova York: Oxford University Press, 2012);

Mattias Kumm, "A virada cosmopolita no constitucionalismo: uma concepção integrada do direito público", Indiana Journal of Global Legal Studies 20 (2013): 605-628.

Cf. Horace, The Odes 1.35.17-20, ed. Niall Rudd, Loeb Classical Library (Cambridge MA: Harvard University Press, 2004): A maioria das tarefas precisas à sua frente, transportando feixe de luz, pregos e cunhas em sua mão de bronze, não esquecendo o grampo imóvel e chumbo para derreter.].

Cf. A. Wagner, "Necessitas", em Wilhelm Heinrich Roscher, ed., Ausführliches Lexikon der griechischen e römischen Mythologie III.1 (Leipzig: B.G. Teubner, 1902), cols. 70-72.

Cf. Black Law Dictionary, ed. Bryan A. Garner (St. Paul, MN: West Group, 1999), 1053.

Rafael Domingo, org., Principios de Derecho Global, 3. ed. (Cizur Menor: Thomson Aranzadi, 2006$)$, no. 146.

Institutos de Justiniano 3.13 pr. Ed. Paul Krüger, Instituições. Corpus Iuris Civilis, vol. Eu, 16a ed. (Berlin: Weidmann, 1954).

Institutos de Justiniano 3.13 pr. Ed. Paul Krüger, Instituições. Corpus Iuris Civilis, vol. Eu, 16a ed. (Berlin: Weidmann, 1954).

Henry de Bracton, De legibus e consuetudinibus Angliae (sobre a lei e costumes da Inglaterra), ed. George E. Woodbine e Samuel E. Thorne, Selden Society, vol. 2 (Cambridge, MA: Harvard University Press, 1968), 283.

Modestinus, Digest 1.3.40, ed. Alan Watson, The Digest de Justiniano, Filadélfia: University of Pennsylvania Press, 1985).

Antonio Cassese, International Law, 2nd ed. (Oxford: Oxford University Press, 2005), 166.

Cf. Brian D. Lepard, Direito Internacional Consuetudinário: Uma Nova Teoria com Aplicações Práticas (Nova York, Cambridge: Cambridge University Press, 2010).

David J. Bederman, Custom como fonte de direito (Nova York, Cambridge: Cambridge University Press, 2010). 
Tony Honoré, "A Comunidade Humana e Regra da Maioria" (1978), em Tony Honoré, Making Law Bind: Ensaios Legais e Filosóficos (Oxford: Clarendon Press, 1987), 237.

Cf. Francisco de Vitoria, Sobre o Poder Civil, pergunta 1, artigo 1, seções 3-6, ed. Anthony Pagden e Jeremy Lawrence, Francisco de Vitória, Political Writings (Cambridge: Cambridge University Press, 1991), pp. 6-10.

AnnePeters, "Conclusão", em Jan Klabbers, Anne Peters, e Geir Ulfstein, editores, The Constitutionalization of International Law (Oxford, Nova York: Oxford University Press, 2010), 351.

Malcolm N. Shaw, International Law, 6th ed. (Cambridge, Nova York: Cambridge University Press, 2014), 123-128, 178-179.

Robert Kolb, Théorie du ius cogens international: Esswi de releitura do conceito (Geneva: Graduate Institute, 2001).

Mattias Kumm, "Poder Constitutivo, Constitucionalismo Cosmopolita e Direito Pós-Positivista", International Journal of Constitutional Law 14 (2016): 697-711.

Martin Loughlin, Fundações do Direito Público (Oxford, Nova York: Oxford University Press, 2010), 221-228.

Martin Loughlin, "O Conceito de Poder Constituinte", Jornal Europeu de Teoria Política 13.2 (2014): 218-237.

Ernst Wolfgang Böckenförde, "O Poder Constituinte do Povo: Um Conceito Liminal de Direito Constitucional", em Ernst Wolfgang Böckenförde, Teoria Constitucional e Política. Selected Writings, ed. Mirjam Künkler e Tine Stein (Oxford, Nova York: Oxford University Press, 2017), pp. 169-185.

Hannah Arendt, "Karl Jaspers: Cidadão do Mundo", em Hannah Arendt, Homens em Tempos Obscuros (San Diego, Nova York, Londres: A Harvest Book, Harcourt Brace \& Company, 1995), 81.

Neil Walker, "O Retorno do Poder Constituinte: Uma Resposta a Mattias Kumm", International Journal of Constitutional Law 14 (2016): 906-913.

Kumm, "Constituinte de poder, limites eidentidade: na profundidade justificatória do constitucionalismo. Uma réplica para Neil Walker, "International Journal of Constitutional Law 14 (2016): 914-924.

Aristóteles, Política 1.1.1252a, ed. e transl. H. Rackham (Cambridge MA, Londres: Harvard University Press, 1990).

Cf. Tomás de Aquino, Summa Theologiae I-II, q. 90 a. 3 ad 3; Summa Theologiae II - II, q. 65 a. 2 ad 2, e Sententia libri Politicorum 1.1.23 (ed. Enrique Alarcón, Corpus Thomisticum, Universidade de Navarra, 2000, em linha: www.corpusthomisticum.org). 
Tomás de Aquino, ver John Finnis, Aquino: Teoria Moral, Política e Jurídica (Oxford, Nova York: Oxford University Press, 1998), 52, 114, 122, 219, 2211 n. 10, 226 e 307.

Sten Gagnér, Studien zur Iddeengeschichte der Gesetzgebung (Estocolmo: Almqvist \& Wiksell, 1960), 210-240.

De Luscombe e GR Evans, "O Renascimento do Século XII", em James Henderson Burns, org., A História de Cambridge do Pensamento Político Medieval (c.350-c.1450) (Cambridge Nova York: Cambridge University Press; 1988), 306-338, em 336.

Hans Kelsen, Teoria Geral do Direito e do Estado, trad. Andres Wedberg (Cambridge MA: Harvard University Press, 1945), 391.

Kenneth W. Ford e Diane Goldstein, O mundo quântico: física quântica para todos (Cambridge MA, Londres: Harvard University Press, 2005).

Anne Peters, "Constitucionalismo Compensatório: A Função e o Potencial das Normas e Estruturas Internacionais Fundamentais", Leiden Journal of International Law 19 (2006): 579-610.

Ulfstein, "O Judiciário Internacional", 152. Ver também Andreas Føllesdal, Johan Karlsson Schaffer, Geir Ulfstein, A Legitimidade dos Regimes Internacionais de Direitos Humanos: Llegal, Perspectivas Políticas e Filosóficas (Cambridge, Nova York: Cambridge University Press 2014).

Fritz Schultz, Uma História da Ciência Jurídica Romana (Oxford: Clarendon Press, 1946).

Richard A. Bauman, advogados na política de transição romana: um estudo dos juristas romanos em seu cenário político no final da República e Triunvirato (Munique: Beck Verlag, 1985).

Bruce W. Frier, A ascensão dos juristas romanos: Estudos em Pro Caecina de Cícero (Princeton, NJ: Princeton University Press, 1985).

Tony Honoré, Imperadores e Advogados, 2. ed. (Oxford, New York: Oxford University Press, 1994).

Wolfgang Kunkel, Die Römischen Juristen. Herkunft und soziale Stellung, 2ª ed. Reimpressão (Colônia: Bohlau Verlag, 2001).

Recebido em: 20/02/2019

Aprovado em: 25/04/2019 